\title{
Engaging Literary Competence through Critical Literacy in an EFL Setting
}

\author{
Muzakki Afifuddin \\ Universitas Negeri Malang \\ muzakki@live.com
}

\begin{abstract}
In the process of developing students' literary competence, especially in the aspect of the ability to respond appropriately to all literature in a target language, students' literacy in the target language becomes a challenge that a teacher must face. This paper then proposes the initiation of literary competence through critical literacy in the target language. The study involved 84 university students that study English Literature in an EFL context. They were asked to critically read English literary texts and discuss in a group about the texts and then they were asked to write what they think about the texts. Their writings were then analyzed to see the students' ability to response appropriately to the texts in the target language. The 8 students were randomly selected to be interviewed about their attitude and reflection on the critical literacy activities and literary competence. The results show that only small number of students are able to engage in their literary competence within the interactional critical activities. Furthermore, the implementation of the activities of critical reading and discussing about literary texts and writing self-reflections are expected to improve the students' literacy and literary competence.
\end{abstract}

Keywords: Literary Competence, Critical Literacy, Literature, EFL Setting

\section{INTRODUCTION}

In the process of teaching English Literature, the question of enjoyment or quality of reader/text interaction is rarely given a priority in the process. What must be underlined is that in reading literary texts, the quality of interaction is important. Literary comprehension is not just a matter of finding the meaning of sentences, but it is a more flexible and complex process involving total context of the utterance, rhetorical strategies of the text, attitudes, knowledge and expectations of the reader (Gilroy-Scott, 1983). So, a certain unique set of linguistic and personal situations of every reader may enhance their understanding upon a literary text. Thus, the use of reader-centered approaches to comprehension is essential in this situation.

In the process of the course, the teacher must guide and control the course, which in turn implies dialogue between the teacher and the students to come to the best interpretation of the literary text. According to Rodger (1983), this best interpretation is the one that has the greatest number of subjective responses which is correlated with the largest number of demonstrable textual data, without the interference of irrelevances, the omission of crucial evidence, or the loss of interpretative consistency which seeks to

account for the unity of the work. In this kind of discussion, the students need to be explained about the interpretative procedures, to be introduced to how to identify, name and explain stylistic devices. The students also need to be guided to connect their interpretative skill with their sensitivity through continual patient practice in interpretation. So, the students will eventually develop their personal literary competence.

Literary Competence was introduced by Jonathan Culler (1975) that refers to a person's implicit, internalized knowledge of the rules of literature. He also suggests that knowledge of a language and a certain experience of the world do not suffice to make someone a perceptive and competent reader. That achievement requires acquaintance with a range of literature and in many cases some form of guidance. Thus, through guidance, teachers should develop their objectivity in seeing the students' development towards a general literary competence. Furthermore, by guiding the students to build good reasoning, teachers will be able to assess the students' acquisition of the competence rather than the variety of literary works read by the students.

Furthermore, Spiro (1991) defines literary competence as (1) informed appreciation of literature, (2) ability to respond appropriately to all literature in the target language, (3) ability to analyze and define responses in literature, (4) ability to relate literature to one's personal experience/to empathize with text, (5) ability to place literature within a wider social / cultural / linguistic context, and (6) enjoyment of literature. Through the process of critical literacy, the students are then observed whether they undergo these aspects of literary competence.

Critical literacy, Wallace (2001) suggests, is concerned with the relations of power and thus in the manner in which power circulates in the real world and within particular texts. Certainly critical discourse analysis, which has a close link to critical language awareness and in turn with critical literacy, is centrally concerned with the exercise of power as it emerges in the discourses of specific texts. In this context, the exercise of power that the students must be able to provide is their personal engagement within their interpretation about the literary texts. The students then may create their own meaning through the dialogues within their process of critical literacy, since reading, writing, speaking, and listening can be interactional in the process. In reading and listening, students are attempting to make sense of the logic or reasoning of another person, then in speaking and writing, students are expressing their logic or reasoning. All the skills can also interact from listening to writing or reading to speaking.

The implementation of critical literacy in the classroom has been validated through several researches. The first research is a research by Yujong Park (2011) entitled 
Using News Articles to Build a Critical Literacy Classroom in an EFL Setting. Results show that when taught to be critical readers of the text, these EFL participants were able to actively use linguistic resources from the article as well as their own cultural and personal experience to support their ideas and raise questions.

The second research is entitled Understanding Critical Reading in an ESL Class in Singapore by Cynthia Jean Macknish (2011). The study focused on the emergence of critical reading discourse in peer group discussions of texts. Findings show that, despite some limitations, the students engaged in critical reading discourse when they were provided with scaffolding and opportunities to practice.

The last paper is written by John Beaumont (2010) entitled A Sequence of Critical Thinking Tasks. This article presents a sequence of seven critical thinking tasks, a flexible framework that acts as a practical tool for planning and developing level-appropriate classroom materials that encourage and advance critical thinking. The sequence of tasks, originated by Carol Numrich at Columbia University, guides teachers in scaffolding critical thinking and English language skills so that critical thinking may be practiced at any language proficiency level.

This study focuses on the initiation of literary competence through critical literacy in the target language guided by the following questions: a) How does the activity of critical literacy help the students engage with their ability to respond appropriately to all literature in the target language? b) How do the students reflect on their ability to respond appropriately to all literature in the target language after engaging in the process of reading, discussing, and writing about the poems?

\section{METHODS}

This research employs qualitative research design since this study uses text analysis, video/audio recording analysis, observation, and interview within the process of the research. The data of the research were taken during the class of English Poetry from an EFL classroom in a university in Indonesia. There are two classes, each of which comprises 39 and 45 students majoring in English with the majority of the students are the fourth semester students. For the purpose of this research, four meetings are designed as a critical literacy class. The students were asked to critically read English literary texts and discuss them in a group about the poems and then asked to write what they think about the texts. The group discussion is then audio-recorded and noted as the source of the data. At the end of the discussion, students are required to write an individual response paper about the issue raised about the poem. Their writings are then analyzed to see the students' ability to respond appropriately to the poems in the target language. After that, 8 students are randomly selected to be interviewed about their attitude and opinion on the critical literacy activity and literary competence engagement. In-class handouts, response paper written by the students, interviews with the selected students also constitute the main data source, which provides valuable context to the analysis. Classroom interaction is conducted in English, whereas interviews are done in Indonesian.

The data analysis proceeds through three phases. In Phase 1 , the data are initially coded and categorized by reading the response papers and transcripts and identifying the critical literacy process encountered by the students by referring to Numrich's Sequence of Critical Thinking tasks mentioned by Beaumont (2010) (see Table 1). In Phase 2, the data are analyzed to identify the students' literary competence especially the ability to respond appropriately to all literature in the target language based on the theory of literary competence by Spiro (1991). In Phase 3, triangulation of the data becomes possible because data are collected from multiple sources and multiple indicators, and then re-analyzed in more depth according to the established constructs of the researcher's identity.

Table 1. Numrich's Sequence of Critical Thinking tasks

\begin{tabular}{|c|c|c|}
\hline Perspective & $\begin{array}{l}\text { Critical Thinking } \\
\text { Tasks }\end{array}$ & Skills Practiced \\
\hline \multirow{2}{*}{$\begin{array}{l}\text { Focus on the } \\
\text { students, } \\
\text { world }\end{array}$} & 1. Observing & $\begin{array}{l}\text { Looking } \\
\text { Listening }\end{array}$ \\
\hline & $\begin{array}{ll}\text { 2. } & \text { Identifying } \\
& \text { Assumptions }\end{array}$ & $\begin{array}{l}\text { Sharing background } \\
\text { Expressing opinions } \\
\text { Clarifying values }\end{array}$ \\
\hline \multirow[t]{2}{*}{$\begin{array}{l}\text { Focus on the } \\
\text { text }\end{array}$} & $\begin{array}{l}\text { 3. Understanding } \\
\text { and } \\
\text { organizing }\end{array}$ & $\begin{array}{l}\text { Summarizing } \\
\text { Distinguishing relevant } \\
\text { details } \\
\text { Ordering } \\
\text { Classifying } \\
\text { Comparing } \\
\text { contrasting } \\
\begin{array}{l}\text { Explaining cause and } \\
\text { effect }\end{array}\end{array}$ \\
\hline & 4. Interpreting & $\begin{array}{l}\text { Making inferences } \\
\text { Interpreting meaning } \\
\text { Hypothesizing } \\
\text { Theorizing }\end{array}$ \\
\hline \multirow[t]{3}{*}{$\begin{array}{l}\text { Focus } \\
\text { beyond the } \\
\text { text }\end{array}$} & $\begin{array}{l}\text { 5. Inquiring } \\
\text { further }\end{array}$ & $\begin{array}{l}\text { Surveying the public } \\
\text { Interviewing } \\
\text { specialist } \\
\text { Researching }\end{array}$ \\
\hline & $\begin{array}{l}\text { 6. Analyzing } \\
\text { further }\end{array}$ & $\begin{array}{ll}\text { Synthesizing } & \\
\text { information } & \\
\text { Critiquing } & \\
\text { Reflecting on } & \text { related } \\
\text { ideas } & \\
\text { Making } & \text { logical } \\
\text { conclusion } & \\
\text { Reevaluating } & \\
\text { assumptions } & \\
\end{array}$ \\
\hline & $\begin{array}{ll}\text { 7. } & \text { Making } \\
\text { decisions }\end{array}$ & $\begin{array}{l}\text { Proposing solutions } \\
\text { Problem solving } \\
\text { Taking action } \\
\text { Participating }\end{array}$ \\
\hline
\end{tabular}




\section{RESULTS AND DISCUSSION}

This section is divided into three parts based on the types of the data sources with acknowledging the indicators of literary competence and critical literacy.

\subsection{Response Papers}

Before having the students done the response papers, the classroom is provided with the presentation of the basic knowledge related to English Poetry. Then, the class is divided into groups of four students and they are asked to discuss a poem entitled "Epitaph" by Walter De la Mare. After the discussion, the researcher gives another poem entitled "One Perfect Rose" by Dorothy Parker. Assuming that the students are already familiar with the discussion activity, after the second discussion, the students are obliged to write a response paper that focuses on the speaker of the poem and the attitude of the speaker about the subject in the poem. The students are given 10 - 15 minutes after the group discussion to write an individual response paper in about 100 words. The finding of response papers shows that only 10 papers $(12 \%)$ out of 84 response papers express are more critical than the others. One of the strongest critical literacy is shown by the paper below:

I think the speaker of the poem is a faithful woman, based on two reasons. First, at the beginning of the poem the woman mentioned that the rose given by her husband (probably) is the most perfect thing. Second, in my opinion, I interpret the rose is like a bride price (mahar) (dowry) because it unites their love at the beginning. I think the tone of this poem is about loyalty because of two reasons. First, when the woman talked about something else, she still stated that the rose was the perfect one. Second, flower is a symbol of loyalty (MAA).

The repetition of the pronoun "I" and the use of the possessive pronoun "my" in the writing above show that the student exercises power or critical literacy. Although the poem is actually satiric, the writer tries to see from the perspective of loyalty of the woman to the man. The paper also shows that the student tries to interpret the poem based on his socio-cultural background. Based on Numrich's Sequence of Critical Thinking tasks, the mentioning of the word mahar or dowry reflects that he practices the critical thinking tasks of interpreting, making logical conclusions, and reflecting on related field. He tries to relate the situation in the poem to his socio-cultural background; that is his values about relationship and Islamic concept of marriage.

Based on Spiro's indicator of literary competence, the response paper above shows a certain level of literary competence. The writer is able to perform informed appreciation of literature focusing on the words "speaker", "tone", and "symbol" as part of his writing. The writer is also able to respond appropriately in English although the grammar and diction are not accurate. He shows that he can analyze his response to the poem. The strongest part of his literary competence is the ability to relate the poem to his personal experience. As previously mentioned that the poem is actually satiric, the writer seems to empathize to the speaker of the poem, unintentionally, diverting his interpretation of the satire to a romantic poem thus resulting to the ability to place the poem into his socio-cultural context. This engagement may result in the writer's enjoyment of the poem.

Providing the students with the prompt "I think" at the beginning of their writings may trigger their higher order of thinking to use some information which is beyond the text and show confidence of opinion in the writing. Thus, the use of higher order thinking skills engages the performance of literary competence when the students are provided with the literary texts as the object of the thinking.

\subsection{Group Discussion}

The researcher starts the activity by dividing the class into groups consisting of four students each. The process of discussion starts with one of the students of the group reading aloud the poem while the others are listening and reading the poem by heart at the same time. Based on Numrich's Sequence of Critical Thinking tasks, the students show that they are at the sequence of observing and listening. After the reading, another student starts the discussion by raising a question about the speaker and the tone of the poem. In the process, they choose to start the discussion by finding the meaning of the difficult words. Since the students are trying to focus on the text, they critically distinguish relevant details of the poem, make inferences, and interpret meaning as shown by the data below:

M: So, the first question is what is the attitude of the speaker towards the subject "Him"? so the attitude... What do you think?

(students grumbles several words)

F: But, first. What is the "lagging" mean here?

M: Okay, let me check.

$B:$ (in Indonesian) Indonesia, ketinggalan

M: (in Indonesian) Ketinggalan. Haste?

F: Lest?

M: (reading the poem) Lest while you're lagging

(students grumble several words)

S: (in Indonesian) Kalau. Agar tidak.

M: (reading the poem) I remember him

F: I think the speaker's hatred, with hatred, err you know, feel towards "Him" here.

M: I think, wait. The speaker here, Emily Dickinson, she talks to her own heart.

$F$ : Yeah, to herself.

M: So, she told with herself like "Heart, we will forget him." "We" here refers to Emily, I mean, the author or the writer and also the heart. Yeah. "We will forget him. You and I. Tonight" like that.

S: So it is kind of avoid heart? (grumbles) (in Indonesian, confirming) ya khan?

The literary competence that the students show in this data is the ability to respond appropriately to all literature in the target language. The students try to respond the poem by finding the meaning of the poem in their own words so that they can feel the sense of the words closely. Student F is the 
one who reads the poem aloud before the group discussion. Student $M$ then tries to lead the group discussion by asking the question. She seems to be the one who can express her informed knowledge of poetry. Then the others, B and S, are following her and responding to the discussion by helping student $\mathrm{F}$ to look for the meaning of the words in Indonesian. The student $\mathrm{F}$ seems like she is processing in her mind until she makes the first conclusion about hatred. The student $\mathrm{F}$ shows the ability to analyze and define responses in literature although she seems to think that it is not the last conclusion. Students B and S, although they choose not to talk much in this part, are critically listening to what the others are talking. They choose to cooperate to the students $\mathrm{F}$ and $\mathrm{M}$ and help them in improving the interpretation of the poem.

Based on Numrich's Sequence of Critical Thinking Skills, the students have practiced the skills of critical thinking tasks although not sequentially. When applied interactionally, the students practice the critical thinking tasks based on their own perspectives. The process of their thinking becomes dynamic because the students change perspectives occasionally from their own world, to the text, and beyond the text. The students practice their critical thinking, through critical speaking, listening, reading, and writing, to express their thought of interpretation about the poem. Thus, the critical literacy activities raise the students' literary competence when the activities focus on literary texts.

\subsection{Focused Group Interview}

The data of the interview is taken right after the modification of the class into groups of four students. The interview starts with asking the students opinion about the difference of classroom activities. The researcher raises the issue of the change of the activities in the classroom from teacher-centered activities to the combined teacher-centered and student centered activities. From both activities, they would prefer the interactional critical activities since it encourages them to apply what they feel they can and what they feel they know. They also feel that they can enrich their vocabulary from the discussion since the friends help them to think about the poems. The students also feel that they can respond the poems better when they are in a group rather than responding to the lecturer.

Relating to their reflection on the literary competence, one of the interviewees answers that the activity helps her to really her analysis in literature especially poetry. She seems to be aware that poetry has multiple interpretations. Then, when in groups, she feels that differences of interpretation help her in understanding the poems in through several perspectives. Another interviewee which seems to be a passive student in the group discussion supports the idea that the group discussion helps her to understand the poems better. Then another interviewee seems to be aware that the application of group discussion in developing personal response papers makes her be able to really engage to the poem personally since every student may have different ways to express and to engage to the poem. She also adds later that she uses her friends as references of interpretations. When asked about whether they can make a personal engagement to the poem, one of the interviewees says that it is not about personal engagement but it is rather putting oneself in the speaker's position.

As reflected by the focused group interview, the students are able to respond appropriately to the literary text in English by the help of the other students through interactional critical thinking activities. Some students may have been aware of their competence but others may not have. The focused group interview, since it is done critically, also engages the students' literary competence.

\section{CONCLUSION}

Critical thinking in the application within the skills of reading, writing, speaking, and listening becomes crucial when thinkers actively circulate their power over themselves, the texts, and beyond the texts. The current study describes the practice of interactional critical literacy at an English literature classroom in an EFL setting. The activities are motivated by the recent change of curriculum from a focus on knowledge to the textual analysis ability. The data used in this study are quite small to draw a conclusion that the activities succeeded in engaging the students' literary competence since only small amount of students are able to perform their literary competence through the response papers. However, the group discussion and the subjects of the focused group interview reported in this study may be representative enough to show that students are able to engage in their literary competence within the interactional critical activities. The use of English poems as texts is possibly the main source for both critical literacy and literary competence in the classroom.

\section{REFERENCES}

Culler, J. (1975) Structuralist Poetics. Routledge. London.

Beaumont, J. (2010) A Sequence of Critical Thinking Tasks. TESOL Journal 1.4 December 2010. pp. 427 - 448

Gilroy-Scott, N. (1983) Teaching Literature Overseas: Language-Base Approaches, Pergamon Press. Oxford.

Macknish, C. J. (2011) Understanding Critical Reading in an ESL Class in Singapore. TESOL Journal 2.4 December 2011. pp. $444-472$

Park, Y. (2011) Using News Articles to Build a Critical Literacy Classroom in an EFL Setting. TESOL Journal 2.1 March 2011. pp. $24-51$

Rodger, A. (1983) Language for Literature In C. J. Brumfit, Teaching Literature Overseas, Language-Based Approaches, Pergamon. Oxford.

Spiro, J. (1991) Assessing Literature: Four Papers in Christopher Brumfit, Assessment in Literature. Macmillan Publishers Limited. London. pp. 16-83.

Wallace, C. (2001) Critical Literacy in the Second Language Classroom: Power and Control in Comber, Barbara and Simpson, Anne. (2001) Negotiating Critical Literacies in Classrooms. Lawrence Erlbaum Associates, Publishers. London. pp. 209-227 